\title{
成人における内因性瞬目の年齢差と性差
}

\author{
東北大学医学部保健学科 \\ 杉山 敏子 ${ }^{11}$ \\ 白滆大学教育学部 \\ 田多 英興
}

\section{Age and gender differences in endogenous eyeblinks and the standard blink rate of normal adults.}

\author{
Toshiko SugIYAma \\ Department of Health Sciences, Tohoku University School of Medicine \\ 2-1 Seiryo-machi, Aoba-ku, Sendai, 980-8575, Japan \\ Hideoki TADA \\ Faculty of Education, Hakuoh University
}

1117 Daigyouji, Oyama, 323-8585, Japan

The major purpose of this study was to establish the standard rate of blinking in adults using relatively large samples of subjects. A subsidiary purpose was to investigate gender and age differences in eyeblink behaviors. The identical task, watching an edited video tape for three minutes, was administered to 671 subjects aged from 20 to 93 years. Eyeblinks of each person were videotaped during task performance and were analyzed using a special software. The results were as follows: (a) the average blink rate in adulthood was approximately 20 blinks per minute, (b) no remarkable age effects was found, but (c) the gender difference in eyeblink rate was significant, with females blinking more frequently than males. In addition, the opening and closing durations of eyeblinks, the synchronization between right and left eyelids, and the effects of wearing contact lenses and eyeglasses on eyeblink rates were examined in terms of age and gender differences. A specific influence of contact lens wearing on blink rate was obtained, namely a significant increase in blinking and prolongation of blink duration. (Japanese Journal of Physiological Psychology and Psychophysiology, 25(3) : 255-265, 2007.)

Key words : endogenous eyeblink, age difference, gender difference, standard eyeblink rate of normal adults.

2006.4.20 受稿, 2007.4.9 受理

1) データの取得に際しては多くの施設と皆様にご協力いただきました。ここに記して深く感謝いたします。ご協力いただいた方々は次の 通りです。仙台市台原老人福祉センター, 宮城県利府町保健福祉センターと仙台市泉中央老人福祉センターの職員の皆様とそこでの企 画に参加されていた皆様, 宮城ふそう仙台支店の皆様, 東北学院榴ヶ岡高等学校の教員の皆様, 公立刈田綜合病院の職員の皆様, 東北 大学病院の看護師の皆様と放射線技師の皆様, 東北大学医療技術短期大学部看護学科の学生の皆様。 
【要 約】本研究は健常成人の内因性（自発性）瞬目の諸属性についてその標準値を得ることを第一の目的とし, さらに年齢差，性差，コンタクトレンズ装着の影響などを検討した。実験参加者は 20 歳代から 93 歳までの男女 成人 617 名で，共通の課題として 3 分間に編集したビデオ刺激の視聴を課し，その際の瞬目をビデオに記録し解 析した。結果は，(a) 成人の標準的な瞬目率はほぼ $20 /$ 分であった，(b) 女性の方が高頻度傾向という性差が認め られたが，(c) 著明な年齢差は認められなかった。さらに，開瞼時間，閉瞼時間，左右眼瞼の同期の程度，瞬目の 時間分布，メガネやコンタクトレンズの影響などを性と年齢段階別に解析した。その結果，コンタクトレンズ装 着者は非装着者に比べて瞬目率が高いことが明らかになった。

\section{はじめに}

ヒトの成人は 1 分間におよそ 20 回の瞬目を行う（Stern, Walrath \& Goldstein, 1984; 田多・山田・福田, 1991; Hart，1992）が，乳幼児はほとんど瞬目をしないとい われている (Ponder \& Kennedy, 1927)。瞬目の発達過 程についての研究は比較的早期に開始されたにもかか わらず，Knorr（1929）以降組織的研究はほとんぞ見 られない。そのような状況の中で Zametkin, Stevens, \& Pittman（1979）の論文が，最も組織的な研究のひ とつであると思われる。その報告によると，瞬目は出 生時にはほとんぞ生起しないが，徐々に増加して青年 期までに安定期に達し, 成人期以降はそれが維持する としている。他にも（Karson, Burns, LeWitt, Foster, \& Newman，1984）同様の報告があるが，これらの結果 はまだ完全に確認されたものではない (Bentivoglio, Bressman, Cassetta, Carretta, Tonali, \& Albanese, 1997)。 そこで筆者らは数年間にわたり，これらの結果を大標 本で確認するために，新生児から高齢者までの瞬目行 動の発達過程に関するデー夕の収集を行ってきた。本 報告は，横断的方法による新生览から高齢者までの瞬 目行動の生涯発達に関する研究の一部である。

したがって,この研究の第一の目的は, 新生児から 高齢者までの約 1400 名の実験参加者のうち, 成人か ら高齢者までの年齢による瞬目の差異に焦点を絞り報 告することである。一般には，その生起因が比較的容 易に特定できる反射性や随意性瞬目以外の瞬目を周期 性，自発性または内因性瞬目（endogenous blink）と 称するが，本稿では Stern et al.（1984）のいう内因性 瞬目の名称を用いる。それは，この種の瞬目には情報 処理過程という高次神経活動が関与する（Stern, 1990） と考えているからである。

第二の目的は成人における瞬目率の性差について検 討することである。瞬目の個人差が大きいということ はよく知られているが，性差についての見解は必ずし
も一致していない（南・山城・南, 1957; Norn, 1969)。 ある研究者達は, 瞬目率は男性よりも女性の方が高い (Ponder \& Kennedy, 1928; Peterson \& Allison, 1931; Newhall, 1932; Zametkin et al., 1979; 田野, 1995 ; 田 多, 1996 ; Stern, Boyer, Schroeder, Touchstone, \& Stoliarov, 1996; 田多・皆川, 1996; Bentivoglio et al., 1997）としているが，差がないという報告も多い （長田・斎藤・太田・中村・崔・楠本 - 谷嶋, 1990 ; Yolton, Yolton, López, Bogner, Stevens, \& Rao, 1994 ; Doughty, 2002)。これらの研究はいずれも標本数が少 なく, 性差そのものを目的にした研究ではないため, 性差の原因について明確に論じてはいない。本研究で はまず大標本によってこの性差の存在の有無を確認す ることを目的とした。

一般に，内因性瞬目の研究は，実験参加者内と被害 験参加者間デザインの 2 つのタイプに分けることがで きる。実験参加者内デザイン実験の場合, 実験参加者 に対して課題遂行の前後の瞬目率を比較することで条 件は満たされるため, 瞬目の標準あるいは基線水準は それほど重要な役割を果たさない。これに対して，実 験参加者間計画の実験の場合, 通常健常者の瞬目率が 統制群の値として設定されるため，その統制群の瞬目 の基線水準が非常に重要になる（田多・杉山，2006）。 この方面の最も優れた研究者の一人である C. N . Karsonの研究を検討しても，基準值となる統制群の 健常成人の瞬目率は, 最小 15.0 回／分（以下この単 位を bpm（Blinks Per Minute）と表記する), 最大 26.0bpm, という大きな開きがあるのが現状である（田多・杉山， 2006)。これは必ずしも彼らの研究上のミスではなく, 瞬目が本来もつ広範囲に及ぶ個人差に由来するところ が大きいと考えられる。したがって瞬目率の基線水準 は報告によって異なることになる。

Doughty（2001）はこの事実に強い注意を払い，内 因性瞬目研究に関する 53 件の論文を総覧した。その 
結果, 報告ごとに基線瞬目率に大きな幅があるために, 本質的には基線瞬目率は存在せず，具体的には読書瞬 目率, 安静時瞬目率, あるいは会話瞬目率があるに過 ぎないのではないか。つまり, Stern et al. (1984) が 主張するような「課題要求」ごとの瞬目しか存在しな いと記述している。しかし，ある程度正確な基準值を 共有することがない限り比較研究そのものが成立せず, 研究ごとに恣意的に基準值を採用した場合，正確な瞬 目の機構解明には至らない。そこで, 本研究の第三の 目的は, これらの問題の一部を解決するために, 大標 本でありかつ均質の実験条件のもとで, 詳細な記録と 解析を行うことにより, 健康な成人の瞬目率の基準值 あるいは標準值を得ることである。

また，瞬目行動について多角的にその特徵を記述す ることが瞬目のメカニズムを理解するために有益と考 えられる (Stern et al., 1984）ため, 従属変数として, (a) 瞬目率, (b) 瞬目時間, (c) 両眼瞼の同期の程度, (d) 群発瞬目の発生率を測定した。両眼瞼の同期や群 発瞬目については現在あまり注意が向けられていない が，例えば Bentivoglio et al.（1997）は“瞬目の群発 は眼瞼痤攣と運動性チックの 2 つの神経学的状態の特 徵的サインになる”ことを予測しており，この指標が 将来は神経学的特徵の有力なサインになる可能性があ る。したがつて, この研究の第四の目的は, 特に左右 閉瞼の同期と群発瞬目に焦点を絞り, 瞬目におけるこ れらの指標の有効性を検討することである。

\section{方法}

実験参加者 617 名の実験参加者の内訳を Table 1 に示す。年齢集団は, 20 代（20-29歳）から 80 代（80 歳以上）まで 10 歳単位で 7 群を設けた。90歳以上の 実験参加者は 80 代に含めた。20 代から50 代の実験参 加者の職業は, 看護師, 病院事務, 放射線技師, 自動 車販売会社の社員, 高等学校の教員などであった。60 代以上の高齢者群は退職者か主婦が中心であったが, 週に数回高齢者のための活動に集まるさまざまなキャ リアを持つ健康な人々であつた。また, 裸眼・コン夕 クトレンズ着用者・眼鏡着用者の区別をしたが，その 人数などの内訳は Table 1 に示す。

倫理的配慮 実験を依頼する際に，まずその施設長 または所属長にその内容, 実施方法を説明し了解を得 た。さらに，全ての実験参加者に対して実験開始前に 実験の内容を説明し，承諾を得られた人だけに実験の 協力を依頼し実施した。

課題 全対象群に対して均質の実験条件を設定する 目的で, 全ての実験参加者に対して同じ課題を課した。 課題刺激はドイツの古い町並みを写しているビデオを 3 分間に編集した映像で, 背景音楽はモーツァルトの アイネ・クライネ・ナハトムジークと鐘の音である。 実験参加者の課題は 3 分間そのビデオを見ているだけ である。基線水準の瞬目率を得るために 5 分間記録し ている例も近年出てきた（Doughty, 2002）が，デー夕 収集開始時はまだ 3 分間でよいという説が一般的だつ た (Zaman \& Doughty, 1997; Depue, Iacono, Muir \&

Table 1

Specification of participants

\begin{tabular}{|c|c|c|c|c|c|c|c|c|c|}
\hline \multirow{2}{*}{$\begin{array}{c}\text { Age } \\
\text { Groups }\end{array}$} & \multicolumn{3}{|c|}{ Female } & \multirow{2}{*}{$\begin{array}{c}\text { Female } \\
\text { total }\end{array}$} & \multicolumn{3}{|c|}{ Male } & \multirow{2}{*}{$\begin{array}{l}\text { Male } \\
\text { total }\end{array}$} & \multirow{2}{*}{ Total } \\
\hline & $N E$ & $\mathrm{CL}$ & $\mathrm{GL}$ & & $\mathrm{NE}$ & $\mathrm{CL}$ & GL & & \\
\hline $20 \mathrm{~s}$ & 22 & 29 & 3 & 54 & 25 & 20 & 6 & 51 & 105 \\
\hline $30 \mathrm{~s}$ & 16 & 20 & 3 & 39 & 25 & 6 & 16 & 47 & 86 \\
\hline $40 s$ & 31 & 9 & 22 & 62 & 11 & 1 & 25 & 37 & 99 \\
\hline $50 \mathrm{~s}$ & 15 & 3 & 22 & 40 & 14 & 1 & 22 & 37 & 77 \\
\hline $60 \mathrm{~s}$ & 38 & 0 & 15 & 53 & 13 & 0 & 16 & 29 & 82 \\
\hline $70 \mathrm{~s}$ & 35 & 0 & 25 & 60 & 21 & 0 & 25 & 46 & 106 \\
\hline $80 \mathrm{~s}$ & 19 & 0 & 23 & 42 & 12 & 0 & 8 & 20 & 62 \\
\hline Total & 176 & 61 & 113 & 350 & 121 & 28 & 118 & 267 & 617 \\
\hline
\end{tabular}

Note. $\mathrm{NE}=$ naked eyes $; \mathrm{CL}=$ with contact lenses $; \mathrm{GL}=$ with glasses. 
Arbisi, 1988）ため, この研究では3 分間の課題とした。 実験条件により一度に 1 名から 6 名一組で実験を行つ た。

記録装置と実験室 ビデオ映像を見ている間の実験 参加者の瞬目を記録するために，実験参加者一人につ き一台のデジタル・ビデオ・カメラを使用した。カメ ラは民生用のデジタルカメラである, Sony DCRVX2000 とその類似品で, 1 秒 30 フレームの精度であ る。実験場所は実験参加者の所属している会社, 学校, 病院, 老人施設, などでそれぞれの施設で許される範 囲の部屋を使用させてもらつた。場所の条件によって, 14 ～ 20 インチのテレビに刺激を提示し， その前に 1 〜6名が平均的に見えるように椅子を配置して見ても らった。また, デジタルビデオカメラを三脚に固定し, 実験参加者からおよそ $1.5 \mathrm{~m}$ の位置にセットした。撮 影の前に画面に顔全体が入るように調整した後, 録画 ボタンを押して映像が終了するまでそのまま録画を継 続した。動きが多い実験参加者や画面からはずれてし まった実験参加者 34 名は瞬目属性の測定は行わず, 瞬目数のみを目視で計測し瞬目率に換算した。

ビデオの解析 ビデオに収録された瞬目映像はパー ソナルコンピュータ（SONY 製 VAIO PCV-L730/BP, PCG-984N を中心何種類かのコンピュータを使用し た）に取り达んだ後, DITECT 社製の運動解析ソフト Dipp Motion 2D（このソフトはさまざまな運動の解析 を目的にして開発されたものであるが, 今回はさらに 特注で瞬目検出機能を加えた）によって虹彩の重心を 座標化した。また同時に顔の動き（主に耳架）も座標 化し, その後座標化された虹彩の重心から顔の動きを 座標上で減じることによって, 眼瞼の運動に相当する 波形を得た。この波形は眼球電図 (EOG： electrooculogram, 以後 $\mathrm{EOG}$ とする）と同様の変化を示す。今回は, 特 に左右の眼瞼の動きの差を知るために左右の眼瞼の動 きを検出した。このソフトは基本的に全て自動検出の ためのソフトである。しかし，なおノイズなどにより いくつかの検出ミスもあるため, さらにそこから得ら れたデータはもうひとつの独自に開発したソフト（水 野ソフト製Event Marker) によって, 実際のビデオ映 像とDipp Motion2Dから得られた波形とを照合しなが ら瞬目を確認し, 手動で検出瞬目の編集（追加, 除去, 波形の修正など）を行つて, 最終的な瞬目として同定 した。その際睲孔を眼瞼によって完全に覆われたもの
を 1 回の瞬目として確認した。瞬目と同定すると自動 的に下記の諸属性が算出される。詳細は別稿（田多・ 高橋・相川・杉山，2006）に記載した。

得られた瞬目指標 その結果最終的に得られた瞬目 指標は，以下の測度である。

(a) 瞬目率 : 3 分間測定した瞬目数から 1 分間の平均值 に換算したもの。

(b) 閉瞼時間 : 瞬目開始から眼瞼が最下部（ピーク） に到達するまでのフレーム数を計測し，そのフレー ム数に $1 / 30 \mathrm{~s}$ を乗じて時間に換算した值。

(c) 開瞼時間：開瞼開始から完全に開瞼するまでのフ レーム数に $1 / 30 \mathrm{~s}$ を乗じて時間に換算した值。

(d) 瞬目時間：閉瞼時間と開瞼時間を加えた値。瞬目 開始から瞬目終了までの時間。

(e) 左右それぞれの眼瞼のピークに達した時間（以下 ピーク時間とする）：各実験参加者の全瞬目の両眼 間のピーク時間の差の平均值を求めた。ピーク時間 の差が $0 \mathrm{~ms}$ のものは同調として取り扱つた。

(f) 群発瞬目の頻度: 群発瞬目は, 瞬目間間隔が $0.5 \mathrm{~s}$ 以下で連続して発生する瞬目を指す。

\section{結果}

\section{瞬目率}

20 歳代の青年から高齢者までの平均瞬目率の変化 をFigure 1 に示した。コンタクトレンズ着用の瞬目へ の影響については後述するが, コンタクトレンズ着用 が大きく影響していたため，ここではコンタクトレン ズを着用していない 528 名と, コンタクトレンズを着

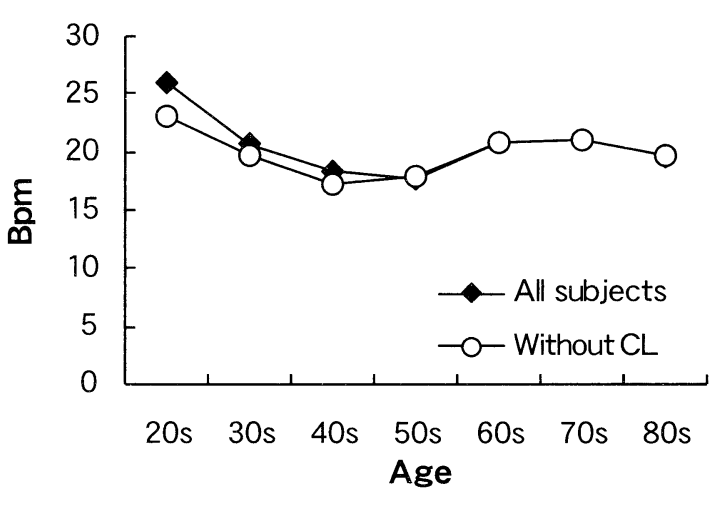

Figure 1. Blink rates as a function of age and groups between all subjects and without contact lens (CL). 
用した実験参加者を含めた 617 名についての結果を示 した。

また年代・性別の瞬目率（コンタクトレンズを着用 している実験参加者は含まない実験参加者 528 名）の 基本統計量を Table 2 に示した。瞬目率の全体の平均 值（コンタクトレンズ着用者を含まない）は，19.9土 14.6bpm（平均值士標準偏差, 以下同様に示す), また, 男性 $18.2 \pm 14.4 \mathrm{bpm}$, 女性 $21.3 \pm 14.7 \mathrm{bpm}, 20-50$ 代 の成人は $19.2 \pm 12.2 \mathrm{bpm}, 60-80$ 代の高齢者は 20.7 \pm $16.9 \mathrm{bpm}$ であった。性と年齢の 2 要因の分散分析では, 女性の瞬目率が有意に高かった（性要因 $F （ 1 ， 514 ）$ $=4.54, p<.05)$ が，年齢要因では主効果は見られなかっ た $(F(6,514)=1.25$, n.s. $)$ 。交互作用はなかった（ $F$ $(6,514)=.51$, n.s. $)$ 。

\section{瞬目率分布}

Figure 2 では，成人（20-50 代）と高齢者（60-80 代）の瞬目率の分布の特徵を表現するために，それ ぞれの瞬目率の分布を示した。図に見るように，20-
50 代の瞬目率のピークは 11-20bpm にあり，60-80 代 では 0-10 bpm にピークが移動し逆 J- 型の分布を示し, 頻度の低い人が多いことが分かる。一方, 瞬目率が

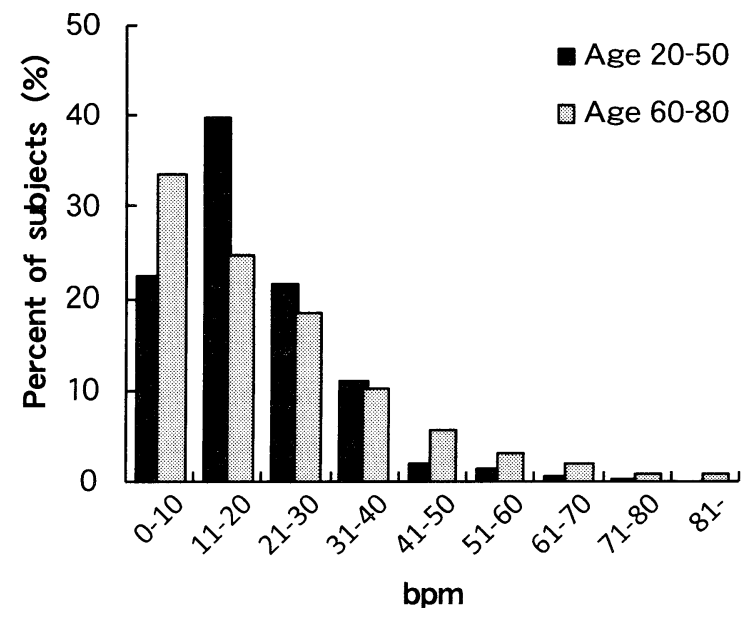

Figure 2. Distributions of blink rates in people aged 20-50 and 60-80.

Table 2

Basic values of blink rate as a function of gender and age without contact lenses

\begin{tabular}{|c|c|c|c|c|c|c|}
\hline Age groups & Gender & $\mathrm{N}$ & $\begin{array}{l}\text { Mean } \\
(\mathrm{bpm})\end{array}$ & SD & $\begin{array}{c}\text { Min. } \\
\text { (bpm) } \\
\end{array}$ & $\begin{array}{l}\text { Max. } \\
(\mathrm{bpm})\end{array}$ \\
\hline \multirow{3}{*}{$20 \mathrm{~s}$} & Female & 25 & 24.0 & 13.2 & 6.0 & 62.7 \\
\hline & Male & 31 & 22.2 & 15.2 & 27 & 79.7 \\
\hline & Total & 56 & 23.0 & 14.2 & 27 & 79.7 \\
\hline \multirow{3}{*}{$30 \mathrm{~s}$} & Female & 19 & 19.1 & 10.1 & 3.7 & 38.0 \\
\hline & Male & 41 & 20.1 & 12.2 & 3.3 & 53.0 \\
\hline & Total & 60 & 19.8 & 11.5 & 3.3 & 53.0 \\
\hline \multirow{3}{*}{$40 s$} & Female & 53 & 18.7 & 11.3 & 1.0 & 56.0 \\
\hline & Male & 36 & 15.4 & 11.9 & 0.0 & 67.0 \\
\hline & Total & 89 & 17.3 & 11.6 & 0.0 & 67.0 \\
\hline \multirow{3}{*}{$50 s$} & Female & 37 & 19.6 & 11.5 & 5.3 & 55.3 \\
\hline & Male & 36 & 16.3 & 11.1 & 0.0 & 50.7 \\
\hline & Total & 73 & 18.0 & 11.4 & 0.0 & 55.3 \\
\hline \multirow{3}{*}{$60 \mathrm{~s}$} & Female & 53 & 23.2 & 15.0 & 0.7 & 75.3 \\
\hline & Male & 29 & 16.7 & 13.3 & 1.0 & 57.3 \\
\hline & Total & 82 & 20.9 & 14.7 & 0.7 & 75.3 \\
\hline \multirow{3}{*}{$70 \mathrm{~s}$} & Female & 60 & 23.3 & 17.7 & 0.3 & 69.0 \\
\hline & Male & 46 & 18.1 & 19.0 & 23 & 82.3 \\
\hline & Total & 106 & 21.1 & 18.4 & 0.3 & 82.3 \\
\hline \multirow{3}{*}{$80 s$} & Female & 42 & 19.9 & 18.1 & 0.3 & 86.0 \\
\hline & Male & 20 & 19.2 & 15.4 & 0.0 & 47.7 \\
\hline & Total & 62 & 19.7 & 17.1 & 0.0 & 86.0 \\
\hline
\end{tabular}

Note. Blinks per minute $=\mathrm{bpm}$. 
$41 \mathrm{bpm}$ 以上の高頻度の比率でも 60-80 代の割合が成人 よりも大きい。つまり，60-80 代は20-50 代に比較し て低頻度傾向者の比率が高く，また高頻度傾向者の比 率も高いことが観察できる $\left(\chi^{2}=26.5>\chi^{2}(8,0.05)=15.5\right)$ 。

\section{瞬目時間}

瞬目時間の結果を Figure 3 に示した。閉瞼・開瞼・ 瞬目時間別を記述する。

閉瞼時間 閉瞼時間の 494名（コンタクトレンズ着 用者を除き測定可能であった実験参加者数）全体の平 均值は $121.7 \pm 16.2 \mathrm{~ms}$ であった。Figure 3 を見ると, 閉瞼時間は性・年齢要因とも明らかな差は見られず, ほとんど一致しているように見える。しかし，2要因 分散分析を施すと, 年齢要因において有意な主効果が 認められた $(F(6,480)=3.35, p<.01)$ 。しかし, 性要 因の主効果 $(F(1,480)=.71$, n.s. $)$ も, 交互作用 $(F(6$, 480）=.90, n.s.）も有意差は見られなかつた。年龄要

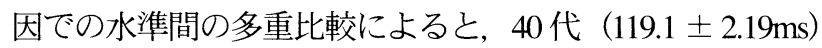
と 70 代 $(127.3 \pm 2.57 \mathrm{~ms}) \quad(p<.05), 40$ 代と 80 代 $(126.0$ $\pm 3.47 \mathrm{~ms} ）(p<.05)$ において有意差が認められ，高齢 者に比べて 40 代の閉瞼時間が有意に短いことが示さ れた。

開瞼時間 同様に開瞼時間の全体の平均値は 280.9 $\pm 46.3 \mathrm{~ms}$ であった。性と年齢の 2 要因分散分析によ れば，性要因では女性の開瞼時間が長く有意な主効果 が得られたが $(F(1,480)=5.21, p<.05)$ ，年齢要因で は有意差は認められなかった $(F(6,480)=.71$, n.s. $)$ 。 また，交互作用はなかつた $(F(6,480)=.27$, n.s. $)$ 。

瞬目時間 閉瞼時間と開瞼時間の合計である瞬目時 間の全体の平均值は $402.4 \pm 50.8 \mathrm{~ms}$ であつた。2 要因

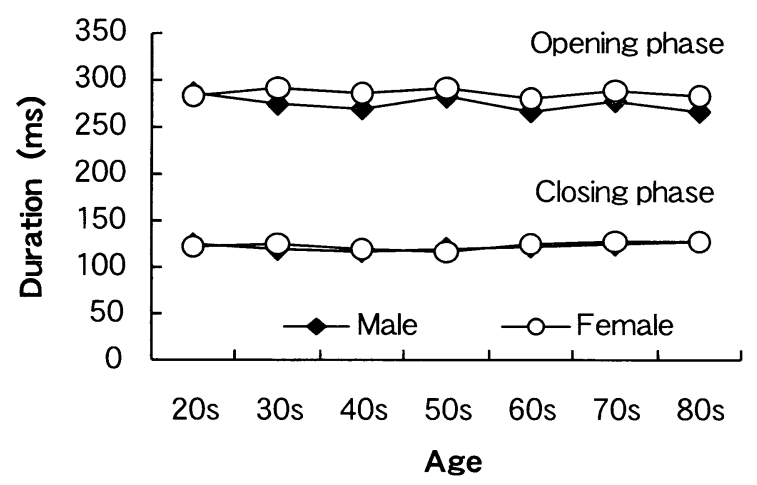

Figure 3. Blink durations in closing and opening phases as a function of age and gender.
分散分析では，性要因には女性が有意に長い主効果が 認められたが $(F(1,480)=6.19, p<.05)$, 年齢要因の 主効果 $(F(6,480)=.84$, n.s. $)$ にも交互作用（F（6, 480）=.30, n.s.）にも有意差はなかつた。

これらの結果から，瞬目時間は女性のほうが長く, それは開瞼に要する時間が長いことが主因であること が示された。

\section{コンタクトレンズ着用の影響}

当初コンタクトレンズ着用の条件は考慮せずに解析 した結果，上記の瞬目率には性差に加えて，年齢差の 主効果も現れた。しかし，コンタクトレンズ着用者を 除いて解析し直してみると, Figure 1 に見られるよう なコンタクトレンズ着用者と非着用者では著しい差が 認められた。さらに, 詳しく解析すると, 以下の 2 点 に影響することが明らかになった。

瞬目率 純粋にコンタクトレンズの効果を検討する ために，ここでは Table2からも明らかなように，60 代以上になるとコンタクトレンズ使用者はほとんどい ないため，20 代から 50 代までの 367 名の実験参加者 に限って比較検討した。Figure 4 に眼鏡やコンタクト レンズ着用時の瞬目率を示す。コンタクトレンズを着 用していると瞬目率のピークが瞬目率増加方向にずれ ることがわかる。それぞれの平均值は, 裸眼 $19.2 \pm$ $11.9 \mathrm{bpm}$, コンタクトレンズ $26.7 \pm 14.0 \mathrm{bpm}$, 眼鏡 $19.1 \pm 12.7 \mathrm{bpm}$ であった。そこで, 裸眼, コンタクト レンズ, 眼鏡の 3 水準の 1 要因分散分析を行うと主効 果が得られ $(F(2,366)=11.69, p<.01)$, 多重比較の 結果コンタクトレンズ>裸眼 $(p<.01)$, コンタクトレ ンズ>眼鏡 $(p<.01)$ とコンタクトコンタクトレンズ

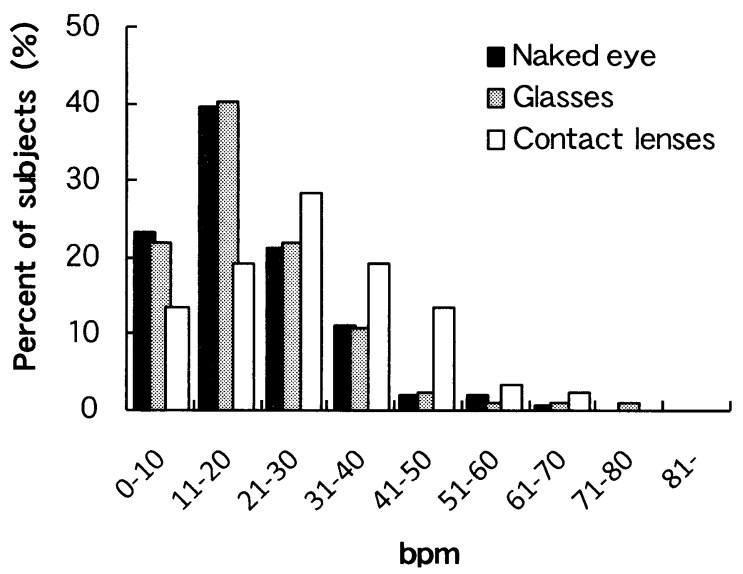

Figure 4. Distributions of eyeblink rates as a function of eye conditions. 
群の瞬目率が有意に高く，裸眼と眼鏡には有意差はな かった。

閉瞼時間・開瞼時間・瞬目時間 さらに，同じ条件 で閉瞼・開瞼・瞬目時間を分析すると, Figure 5 に見 られるように，閉瞼時間ではコンタクトレンズ群は眼 鏡群よりも有意に時間がかかり $(F(2,362)=3.91$, $p<.05$, コンタクトレンズ>眼鏡 $(p<.05))$, 開瞼時間 では, コンタクトレンズ群は眼鏡群より, 裸眼群は眼 鏡群より時間がかかることが示された（F（2,362） $=5.57, p<.01$, 裸眼 $>$ 眼鏡（ $p<.05 ）$, コンタクトレンズ $>$ 眼鏡 $(p<.01))$ 。したがって，コンタクトレンズ着 用時は瞬目率が高く，一回の瞬目に時間がかかること が考えられ，眼鏡着用時は裸眼条件と比較すると，瞬 目率は同率であるが，瞬目時間が短いことが示された。

\section{両眼瞼のピーク時間の同期}

両眼瞼のピーク時間と群発瞬目について，正確に検 出できた実験参加者数は 470 名（コンタクトレンズ着 用者を除く）であった。両眼瞼の同期の程度を検討す
るために，左右閉瞼のピーク点を比較して，左眼瞼の ピークが早い実験参加者の割合 (Left), 右眼瞼のピー クが早い実験参加者の割合（Right），そして左右が 1 フレームも差がなかった実験参加者の割合（Synch.）を, 男女別，年齢群別に Table3 に示した。今回は健常な 実験参加者の特徵をとらえるために，実験参加者の人

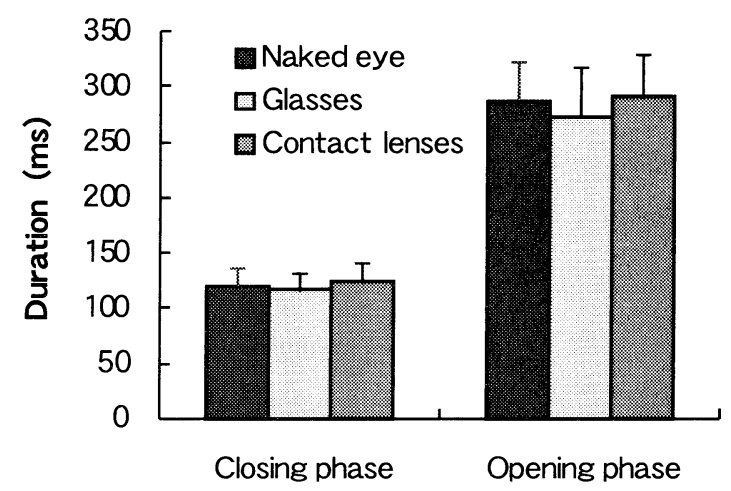

Figure 5. Blink durations in closing and opening phases as a function of eye conditions.

Table 3

Synchronization frequency of both eyelids in peak time as a function of age and gender

\begin{tabular}{|c|c|c|c|c|c|c|c|}
\hline \multirow{2}{*}{$\begin{array}{c}\text { Gender } \\
\text { Age groups }\end{array}$} & \multicolumn{3}{|c|}{ male } & \multicolumn{4}{|c|}{ Female } \\
\hline & $20 s-50 s$ & $60 s-80 s$ & & $20 s-50 s$ & & $60 s-80 s$ & \\
\hline Right & 41 & 20 & & 38 & & 48 & $\Delta$ \\
\hline Left & 44 & 35 & $\Delta$ & 29 & $\nabla$ & 40 & \\
\hline Synch. & 55 & 19 & $\nabla$ & 56 & $\Delta$ & 35 & $\nabla$ \\
\hline
\end{tabular}

Note. Right= the number of subjects whose right eyelid closed earlier than left eyelid ; Left $=$ the number of subjects whose left eyelid closed earlier than right eyelid; Synch.=the number of subjects whose eyelids synchronized blinks perfectly. $\nabla=$ significantly-low, $p<.05 ; \boldsymbol{\Delta}=$ significantly-high, $p<.05$.

Table 4

Flurry frequency as a function of age and gender

\begin{tabular}{|c|c|c|c|c|c|c|c|c|}
\hline \multirow{3}{*}{$\begin{array}{c}\text { Gender } \\
\text { Age groups } \\
\text { Single }\end{array}$} & \multicolumn{4}{|c|}{ Male } & \multicolumn{4}{|c|}{ Female } \\
\hline & \multicolumn{2}{|c|}{$20 s-50 s$} & \multicolumn{2}{|c|}{$60 s-80 s$} & \multicolumn{2}{|c|}{$20 s-50 s$} & \multicolumn{2}{|c|}{$60 s-80 s$} \\
\hline & 6463 & $\nabla$ & 3190 & $\nabla$ & 6998 & $\Delta$ & 7022 & $\Delta$ \\
\hline Double & 972 & $\Delta$ & 442 & & 794 & $\nabla$ & 782 & $\nabla$ \\
\hline More over & 325 & & 249 & $\Delta$ & 256 & $\nabla$ & 308 & \\
\hline
\end{tabular}

Note. Single $=$ blinks whose interval are longer than $0.5 \mathrm{~s} ;$ Double $=$ two consecutive blinks whose intervals are shorter than $0.5 \mathrm{~s}$ respectively ; More over $=$ three or more consecutive blinks whose intervals are shorter than $0.5 \mathrm{~s}$ respectively; $\nabla$ =significantly-low, $p<.05 ; \boldsymbol{\Delta}=$ significantly-high, $p<.05$. 
数割合で算出した。 $\chi^{2}$ 検定では有意差 $\left(\chi^{2}=24.00>\right.$ $\left.\chi^{2}(6,0.01)=16.81\right)$ があり, 残差分析では, 女性男 性ともに高齢者のピーク時間の同調の割合は有意に低 く, 高齢者男性では左眼瞼ピーク時間の早い割合が高 $<$, 高齢者女性の右眼瞼の間が早い割合が高いことが 特徵として示された。

\section{群発瞬目}

群発瞬目の発生比率を, 今回コンタクトレンズを着 用していない実験参加者から検出できた総瞬目数 27,801 個を基にして, 年齢と性別に Table 4 に示した。 群発瞬目の数え方として, $0.5 \mathrm{~s}$ 以下の間隔で連続して 発生した瞬目を 1 回とまとめて表現することもできる が，今回は連続した瞬目であってもそれぞれを 1 回と して計算した。その結果単回瞬目は全体の $85 \%$ を占め, 残りが群発瞬目と言える。2 回連続の瞬目は $11 \%, 3$ 回またはそれ以上のものは4\%以内であった。

$\chi^{2}$ 検定では, 有意差 $\left(\chi^{2}=120.91>\chi^{2}(6,0.01)=16.81\right)$ が認められた。残差分析では, 成人, 高齢者ともに女 性の単回の瞬目の割合が高く, 2 回以上連続する瞬目 は男性に多いことが特徵であった。

一方，個人毎に群発瞬目の生起率を分析したところ 以下の通りとなった。3 分間に全く群発瞬目が発生し なかった実験参加者は 35\%，0～10\%（0は含まない） 発生の実験参加者は 29\%，10～20\% の実験参加者は 15\%, $20 \sim 30 \%$ の実験参加者は 11\%，30 40\% の実験参加 者は 5.8\%，40～50\%の実験参加者は $2.8 \% ， 50 \%$ 以 上の瞬目が群発瞬目で構成されていた実験参加者は 1.7\%であった。

\section{考察 \\ 瞬目の発達と瞬目率の基準値 本研究の第一の目的} として明らかにしようとした成人から高齢者にかけて の標準的瞬目率は $19.9 \mathrm{bpm}$ となり, 先行研究とほぼ一 致した（Karson, Berman, Donnelly, Mendelson, Kleinman, \& Wyatt, 1981; Stern et al., 1984; 田多他, 1991;Hart, 1992）。さらに, 別稿（田多・杉山，2006） で論じた Karson et al.の一連の研究の平均值ともほぼ 一致した。1979 年から 1990 年までの 13 件の論文で, 患者群の瞬目の特徵を比較するために彼らのデータの 統制群平均瞬目率を，筆者らが改めて計算したところ $20.2 \mathrm{bpm}$ であり本結果とよく一致した。ただし, 個々 の論文間ではかなりの開きがあり，その範囲は 15.0 〜26.0bpmに散らばっているということを, 従来の研 究における大きな問題点として指摘した。したがって, これからの比較研究では, 統制群の標準值は $20.0 \mathrm{bpm}$ に近い瞬目率を基準にすることを本研究では提案した い。その值から大幅に外れた瞬目率を, 基準值とする 統制群の瞬目率として設定することはこの上なく危険 であるからである。

一方, 成人から高齢者での瞬目率の変化について分 散分析では有意な差はなかったため, “新生览の瞬目 は極めて低率であるが, 発達とともに増加して, 20 歳でピークに達し, 以後は成人期を通してこの水準を 維持する”という従来の知見 (Zametkin et al., 1979; Karson et al., 1984）を成人から高齢者については追認 するものであった。成人期以降の瞬目は大きな変動は なく, ほぼ同じ水準の瞬目率を維持するものと考えて よいだろう。ただし, Figure 2 に見るように成人と高 齢者の瞬目率の分布をみると, 高齢者の瞬目のばらつ きが大きいことが示されていた。

瞬目率の性差 成人期にある女性の瞬目率が男性の 瞬目率よりも高頻度で, 瞬目時間が長いという本実験 の結果は先行研究によって支持されている（Ponder \& Kennedy, 1927; Zametkin et al., 1979; Stern et al., 1996; Bentivoglio et al., 1997) が, どの論文にもその由来に ついての詳細な説明はない。ひとつの可能性は, ある 種の社会的要求のために女性の顔の表情が男性よりも 豊かであることに起因するという解釈である。根拠の ひとつとして, 新生児からの発達的変化を検討した筆 者らのデー夕 (杉山・田多, 2005a; Sugiyama \& Tada, $2005 \mathrm{~b}$; 杉山・田多, 2005c) では, 成人期において初 めて性差が観察されるのであって, 誕生時から成人に 至る間の年齢群では観察されないという事実があるか らである。あるいは, 生物学的な意味で, 例えば涙の 量に性差があり, 角膜の乾燥の時間に違いが見られる (Henderson \& Prough, 1950) ことなども考えられる。 いずれにしても, 先行研究において瞬目の性差の有無 についての記述はあっても, なぜ性差があるのかその 理由について言及している論文は皆無に近く，この問 題に関しては今後の課題となっている。

瞬目時間 瞬目時間の結果に関しては, 閉瞼時間の 変異は年齢集団間でわずかの差が見られた程度で, 性 差も個人差も極めて小さいことと開瞼時間において女 性がゆっくりと目を開くことが特徵であった。 
瞬目とコンタクトレンズ コンタクトレンズの瞬目 率への影響に関しては従来必ずしも見解は一致してい ない。コンタクトレンズ着用時の瞬目率の著明な増加 を直接指摘する研究も多い（Brown, Chinn, Fatt, \& Harris, 1973; Carney \& Hill, 1984; Tada \& Iwasaki , 1984) が，新井・平井（1992）ではハードレンズの場合に瞬 目は増加し, 完全瞬目回数はコンタクトレンズのサイ ズには大差はなかった。しかし不完全瞬目はレンズが 大きいと増加する結果であったとしている。コンタク トレンズの着用期間は影響しないという報告（Yolton et al., 1994）やコンタクトレンズ着用時の瞬目時間の 延長は角膜上のコンタクトレンズの動きに影響されて いる可能性を指摘する研究（金子・宗像・櫝田，1981） などがありまだ確定的ではない。しかし，コンタクト レンズ着用時は裸眼や眼鏡着用時よりも有意に瞬目率 は増加することを示した本実験の結果から, 実験参加 者間で瞬目数を比較する研究においては, コンタクト レンズ群を除いた方が無難であろう。また, 実験参加 者内で瞬目数を比較する研究においては, コンタクト レンズを着用することで条件が異なる影響を及ぼすの なら，コンタクトレンズを着用した実験参加者を除外 すべきだろう。

瞬目の左右差 瞬目時の左右眼瞼の閉瞼時間や速度 の違いなどを比較した研究は, 顔面神経麻痺の患者（小 松崎, 1987）やあるいはネコ（Spidalieri, Franchi, \& Guandalini, 1997）を対象にした研究, 健常者の随意性 あるいは反射性の瞬目（Kassem \& Evinger, 2006）に ついて検討されているが, 内因性瞬目に関しては筆者 らの知る限りまだ報告はない。Spidalieri et al. (1997) や Kassem \& Evinger（2006）は, ヒトでもネコでも随 意性あるいは反射性さらに条件づけられた瞬目運動に 左右差が認められるが，そのヒト（ネコ）固有の側性・ 癖が認められ，全体を平均すると左右はほぼ等価にな ると述べている。個人固有の個性的行動として眼瞼運 動の非対称が今後の瞬目指標の測度となる可能性もあ るので，本稿では探索的な意味でこの検討を試みた。

左右瞬目の同期に関する今回の結果では, 健康な実 験参加者全体で見た場合には, 左右のピーク時間は完 全に同調している瞬目がおよそ3割, 左右どちらかが 早いものも同比率であり, それらは左右相殺され, 健 康な実験参加者の場合左右ピーク時間は一致するもの と言えるであろう。しかし, さらに詳細に見ると, 年
齢と性などの条件でわずかながら違いが観察されたこ とも注目される点である。特に, 成人女性は両眼瞼の ピーク時間の同調割合が高いこと, 高齢者男性で左眼 瞼のピーク時間が早い割合が高く女性では右眼瞼で高 いこと, 左右眼瞼のピーク時間に性差があり, 男性は 左眼瞼が，女性は右眼瞼が早い傾向が見られたことな どが特記すべき事実である。

てんかん患者の著明な非対称性の報告（Tada， Minakawa, Takenaka, \& Sugiyama, 2004) と今回の結果 を比較すると, てんかん患者の場合の左右不一致はて んかん患者の瞬目の特徵のひとつである可能性がある。 しかし, まだ十分な考察に足るほどの証拠は蓄積され ていないので, これは将来に残された問題のひとつで ある。

群発瞬目 さらに健常成人における群発瞬目の標準 的生起率を得ることが, この研究の目的のひとつであつ た。Table 4 に示したように, 2 回連続, 3 回連続以上 に分類すると群発瞬目全個数での比率は少ないもので あった。

一方, 実験参加者単位で見た場合, 3 分間に全く群 発瞬目が見られなかつた実験参加者は $35 \%$ であり, 健常な実験参加者の場合でも $65 \%$ の実験参加者に群 発瞬目が発生していたことがわかった。また，1割近 い実験参加者は $30 \%$ 以上の瞬目が群発瞬目の形で発 生していた。それがどのような意味を持つかはまだ定 かではないが, 群発が全体の半分以上を占めるような 人の場合, Bentivoglio et al. (1997) の主張するような 病理性を暗示するかもしれないし，あるいは単に個人 的な「癖」なのかもしれない。現段階では解釈の手が かりに欠けるので記述するだけに留めざるを得ない。

\section{結 論}

本研究の結論として以下のことがまとめられた。

(a) 瞬目率に関しては, 20-90 歳までの成人の平均瞬目 率は $19.9 \mathrm{bpm}$ で, 先行研究の報告とほぼ一致した。

(b) 成人期にある女性全体の瞬目率は男性の瞬目率よ りも高いが，明確な年代差はなかった。成人期を通 して一定水準を維持するとする従来の報告と一致し た。

(c) 瞬目時間に関しては, 閉瞼時間には年代差があり 40 代が 70 代・ 80 代よりも有意に速く，また女性の 開瞼時間は有意に長かった。 
(d) コンタクトレンズは瞬目率を増加させ，瞬目時間 を延長させた。

(e) 両眼瞼の同期に関しては, 健康な実験参加者の場 合には左右のピーク時間は一致した。

(f) 群発瞬目は観測された瞬目全体数の $15 \%$ 程度の発 生頻度であったが，実験参加者により発生頻度は異 なり，全く群発瞬目がない実験参加者は $35 \%$ であ る一方， $50 \%$ を群発瞬目で占める実験参加者が $1.7 \%$ 存在した。

\section{引用文献}

新井勝彦・平井美加子（1992）。ハードコンタクトレ ンズ装用による涙液メニスカスの変化 日本コンタ クトレンズ学会誌, 34, 109-114.

Bentivoglio, A. R., Bressman, S. B., Cassetta, E., Carretta, D., Tonali, P., \& Albanese, A. (1997). Analysis of blink rate patterns in normal subjects. Movement Disorders, 12, 1028-1034.

Brown, M., Chinn, S., Fatt, I., \& Harris, M. G. (1973). The effect of soft and hard contact lenses on blink rate, amplitude and length. Journal of the American Optometric Association, 44, 254-257.

Carney, L. G., \& Hill, R. M. (1984). Variation in blinking behavior during soft lens wear. International Contact Lens Clinic, 11, 250-253.

Depue, R. A., Iacono, W. G., Muir, R., \& Arbisi, P. (1988). Effect of phototherapy on spontaneous eye blink rate in subjects with seasonal affective disorder. American Journal of Psychiatry, 145, 1457-1459.

Doughty, M. J. (2001). Consideration of three types of spontaneous eyeblink activity in normal humans: during reading and video display terminal use, in primary gaze, and while in conversation. Optometry and Vision Science, 78, 712-725.

Doughty, M. J. (2002). Further assessment of gender- and blink pattern-related differences in the spontaneous eyeblink activity in primary gaze in young adult humans. Optometry and Vision Science, 79, 439-447.

Hart, W. M. Jr. (1992). The eyelids. In Hart, W. M. Jr. (Ed.), Adler's Physiology of the Eye: Clinical Application, $9^{\text {th }}$ ed., St. Louis: Mosby-Year Book, pp.1-17.

Henderson, J. W., \& Prough, W. A. (1950). Influence of age and sex on flow of tears. Archives of Ophthalmology, 43 224-231.

金子行子・宗像秀子・櫃田光太郎（1981）。眼科用動 的超音波断層装置を用いた瞬目時におけるコンタク トレンズの動きについて 日本コンタクトレンズ学 会誌, 23, 220-225.

Karson, C. N., Berman, K. F., Donnelly, E. F., Mendelson, W. B., Kleinman, J. E., \& Wyatt R. J. (1981). Speaking, thinking, and blinking. Psychiatry Research, 5, 243-246.

Karson, C. N., Burns, R. S., LeWitt, P. A., Foster, N. L., \& Newman, R. P. (1984). Blink rates and disorders of movement. Neurology, 34, 677 - 678.

Kassem, I. S., \& Evinger, C. (2006). Asymmetry of blinking. Investigative Ophthalmology \& Visual Science, 47, 195-201.

Knorr, A.(1929). Beiträge zur Kenntnis des Lidschlages unter normalen und pathologischen Verhältnissen. Würuzburg Abhandlungen aus dem Gesamtegebiet der Medizin, 25, 197-223.

小松崎篤（1987）。瞬目運動による顔面神経機能検査 法 JOHNS, 3, 397-400.

南熊太・山城主計・南ミツ (1957)。瞬目回数に関す る研究（其の 1）正常成人の瞬目回数に就て 臨床 眼科， 11，1012-1014.

Newhall, S. M. (1932). The control of eyelid movements in visual experiments. American Journal of Psychology, 44, $555-570$

Norn, M. S. (1969). Desiccation of the precorneal film. I . Corneal wetting-time. Acta Ophthalmologica, 47, 865880.

長田一臣・斎藤朗・太田浩二・中村絵理・崔二準・楠 本恭久・谷嶋喜代志（1990）。スポーツと自律訓練 （2）一アーチェリー選手の眼瞼運動停止（瞬目耐忍） に関する生理心理学的研究— スポーツ心理学研究, 16, 37-41.

Peterson, J., \& Allison, L. W. (1931). Controls of the eyewink mechanism. Journal of Experimental Psychology, 14, 144-154.

Ponder, E., \& Kennedy, W. P. (1927). On the act of blinking. Quarterly Journal of Experimental Physiology, 18, 89-110.

Spidalieri, G., Franchi, G., \& Guandalini, P. (1997). 
Bilateral coupling in learned blinking: side superiority, synchrony and temporal coordination in normal cats. Brain Research, 746, 34-42.

Stern, J. A. (1990). Blink and you'll miss it. Human Factors Society Visual Performance Technical Group Newsletter, 12, 14-15.

Stern, J. A., Boyer, D. J., Schroeder, D. J., Touchstone, R. M., \& Stoliarov, N. (1996). Blinks, saccades, and fixation pauses during vigilance task performance: II. gender and time of day. $U$. S. Department of Transportation, Federal Aviation Administration, DOT/FAA/AM-96/9, 1-44.

Stern, J. A., Walrath, L. C., \& Goldstein, R. (1984). The endogenous eyeblink. Psychophysiology, 21, 22-33.

杉山敏子・田多英興（2005a），乳幼児における内因性 瞬目の発達 生理心理学と精神生理学, 23, 140.

Sugiyama, T., \& Tada, H. (2005b). Life-long development and sex difference in endogenous eyeblinks (1): adulthood' s standard data from 20's to 80's. Psychophysiology, $\mathbf{4 2}$ (Supplement 1), s119.

杉山敏子・田多英興 (2005c). 幼一少年期の内因性瞬 目の特性 日本心理学会第 69 回大会発表論文集, 444 . 田多英興（1996）。まばたきの個人差と性差。一まば たきで性格がわかるか一 あたらしい眼科，13， $1657-1661$.

Tada, H., \& Iwasaki, S. (1984). Effects of contact lens on the eyeblink frequency during a visual search task. Tohoku Psychologica Folia, 43, 134-137.

田多英興・皆川美雪（1996）。情動喚起刺激に対する
生理反応 一笑いと悲しみビデオへの反応の比較一

人間情報学研究 (東北学院大学)，1，53-66.

Tada, H., Minakawa, M., Takenaka, Y., \& Sugiyama, T. (2004). Endogenous eyeblinks in epilepsy. International Journal of Psychophysiology, 54, 128.

田多英興・杉山敏子（2006）。内因性瞬目の変異の大 きさと被験者群間比較, 東北学院大学教養学部論集,

144, 1-14.

田多英興 - 高橋彌穂 - 相川利樹 - 杉山敏子 (2006). 内因性瞬目の個体・系統発生に関する研究 文部科 学省科学研究費補助金・研究成果報告書

田多英興・山田冨美雄・福田恭介（1991）。瞬きの評 価法と測度 田多英興 - 山田冨美雄 - 福田恭介（編） まばたきの心理学 北大路書房 pp.44-65.

田野礼子（1995）。瞬目と人格特性：集団観察法を用 いて 関西学院大学大学院文学研究科修士論文（未 公刊).

Yolton, D. P., Yolton, R. L., López, R., Bogner, B., Stevens, R., \& Rao, D. (1994). The effects of gender and birth control pill use on spontaneous blink rates. American Journal of Optometric Association, 65, 763-770.

Zaman, M. L., \& Doughty, M. J. (1997). Some methological issues in the assessment of the spontaneous eyeblink frequency in man. Ophtalic and Phsyiological Optocs, 17, 421-432.

Zametkin, A. J., Stevens, J. R., \& Pittman, R. (1979). Ontogeny of spontaneous blinking and of habituation of the blink reflex. Annals of Neurology, 5, 453-457. 